\title{
Development of learning videos of atomic theory concepts of Tialo language
}

\author{
Filza Farhana ${ }^{1,}$ a, Sahrul Saehana ${ }^{1, b}$ *, Lilia Halim ${ }^{2, c}$ \\ ${ }^{1}$ Universitas Tadulako. Jl. Soekarno-Hatta Km. 9 Tondo. Palu - Central Sulawesi, 94118, Indonesia \\ ${ }^{2}$ Universiti Kebangsaan Malaysia. 43600 UKM, Bangi Selangor, Malaysia \\ afarhanafilza95@gmail.com; ${ }^{b}$ sahrul_saehana@untad.ac.id; clilia@ukm.edu.my \\ * Corresponding Author.
}

Received: 17 November 2020; Revised: 11 July 2021; Accepted: 16 July 2021

\begin{abstract}
The purpose of this research is to produce a video learning content on atomic theory. This research uses the design and development design that employs the ADDIE model. The research instrument used was a questionnaire with a four-likert scale admistered on content experts, linguists, media experts, teachers and 10 students of MA AL-KHAIRAAT Tomini. The validity of the content, language and media aspects was said to be good with scores of $3.25 ; 3.33$ and 3.28 respectively. Meanwhile, the scores obtained from teachers and students of class XI IPA were 3.87 and 3.51, both of which were in the "Strongly Agree" category. The results showed that the atomic theory learning video in the Tialo language was suitable for use in learning activities and could increase the concentration level of students. The theoretical implications of this research, namely the instructional video can increase learning motivation in students and the practical implication is that the instructional video is used as resources for teachers and prospective teachers to be used in the learning process.
\end{abstract}

Keywords: tutorial video; atomic theory; Tialo language.

How to Cite: Farhana, F., Saehana, S., \& Halim, L. (2021). Development of learning videos of atomic theory concepts of Tialo Language. Momentum: Physics Education Journal, 5(2), 142152. https://doi.org/10.21067/mpej.v5i2.5054

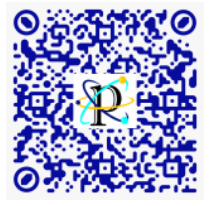

\section{Introduction}

As the understanding of the physical basis of biology increases, and as physics-based technological tools are integrated throughout both biological research and clinical medicine, physics is becoming increasingly valuable in the life scientist's toolkit. Multiple efforts are underway to improve introductory physics for students in the life sciences and allied health fields. A common strategy for reforming such courses includes designing the course to help students make connections between physics and the life sciences, modifying the syllabus to focus on topics and skills most important for biology, and giving the students numerous opportunities to apply physics to "authentic" biological examples-examples in which a biology student or biologist would agree that physics provides useful insights into a biological situation. Courses designed in this way are often referred to as introductory physics for life sciences (IPLS) courses. In our IPLS course, life science examples, such as the optics of vision and the electrical basis of nerve signaling, are central to the course content, and many are revisited multiple times, both qualitatively and quantitatively, and in different settings (i.e., in class, in lab, and on the homework). This provides frequent opportunities for students to work with, reflect on, and make meaningful connections between the life sciences and the physics they need to learn. Such connections are intended to enable students to identify the utility of learning physics, positively influence their feelings about physics, and hopefully support the development of their interest in physics (Crouch et al., 2018). In response to the shortcomings of the develop and disseminate model of instructional change, researchers have advocated for a focus on propagating innovations. In the extreme form of the develop and disseminate model, the developer focuses on 
creating the innovation; it is then disseminated to adopters as a final product to implement on their own. In contrast, the propagation paradigm directs developers to work with stakeholders during the development and adoption process. Change efforts which subscribe to the develop and disseminate model are predominantly concerned with raising awareness of the efficacy of an innovation, whereas change efforts aligned with the propagation paradigm are equally concerned with the usability of the innovation. The propagation paradigm was developed based on a large-scale review of the propagation practices commonly used by STEM education developers and those practices that are used by successfully propagated STEM innovations (such as PhET Interactive Simulations (2020) and ProcessOriented Guided Inquiry Learning, POGIL. Based on this analysis, the propagation paradigm outlines three aspects of effective propagation plans: interactive development of the innovation, interactive dissemination, and ongoing support for stakeholders. In this model, development and dissemination are pieces of a propagation plan, but they are intended to be much more interactive than as enacted in traditional develop and disseminate efforts because the fit of an innovation is a large propagation consideration. Moreover, support for stakeholders acknowledges the variety of contexts in which adopters are situated and this support is the key propagation activity for promoting sustained adoption of an educational innovation. Unfortunately, support for stakeholders-particularly the type of ongoing, people-based support discussed above-is also the least understood propagation activity and work is needed to identify effective support mechanisms This paper addresses that gap in knowledge. One tenet of the propagation paradigm is that a successful propagation plan must be designed based on an understanding of the changes required for sustained adoption of an innovation (e.g., curriculum or teaching method. In order to articulate the changes to current practice that will be required of stakeholders, the propagation paradigm provides guiding questions (Price et al., 2021).

Beginner students have difficulty selecting important information from less important information described as noise when they have to handle too much in their limited working memory. Student misunderstanding becomes an obstacle in obtaining correct knowledge. Whereas many research studies provide evidence of misconceptions, fewer suggest potential solutions. One of them is teaching for conceptual change (Correia et al., 2019). In a situation like this, the teacher himself is aware of his limitations and has new possibilities to develop further, so that his pure function is also present, and the value of his research is very high. This is because a professional teacher can use this situation as an educational tool and use it as an opportunity to develop his professionalism. There are many causes involved in the difficulty teachers face in guiding their inquiry. The teacher views that the teacher himself lacks time to conduct inquiry, does not have the relevant content necessary to guide inquiry, and that the teacher himself lacks understanding and knowledge of inquiry. Many of these studies are related to student free inquiry guides and consist of studies of general inquiry guides, and there are limitations to not providing adequate information about the specific difficulties associated with the content of inquiry. As for the difficulties teachers face in the process of guiding their inquiry, first of all, they can think of textbook variables. Inquiry activities carried out in textbook-based schools are very important to study teachers' perceptions of the difficulties experienced by teachers in guiding textbooks. The inquiry presented in the textbook shows the scientific results obtained through trial and error by many scientists, reorganized and simplified according to the level of the student, thus showing many differences from the actual science (Lee \& Lee, 2018).

Teaching is not just the delivery of content, but also a process of changing student behavior according to the expected goals. Therefore, a teacher needs to educate, guide, and develop the potential of his students. Teachers who support it are able to design and implement various learning models, media, and learning resources to enhance learning experiences (Sumbawat \& Munoto, 2016). For this reason, it is critical to have media that can improve the quality of the teaching and learning process. Learning media is a channel or intermediary used to convey messages or teaching contents. Media is indispensable in learning as a means of conveying information and messages from teachers to students. Good and fluent learning requires good learning media contents and is in accordance with classroom conditions. So that in learning, a media that is able to attract students' attention is needed to pay more attention to the lessons given by the teacher, this media is a learning video (Nurrita, 2018). 
There is also broad agreement among researchers and analysts in science education worldwide that low proficiency in the language of instruction is one of the main causes of low academic performance among students whose mother tongue is different from the language of instruction. They must acquire academic knowledge and skills through decontextualized school languages and must do this through a language they often have not yet fully mastered. Students play an important role mental development and learning in Physics class. Therefore, this means that students' language acquisition needs to be related to the context in which physics lessons take place. When the teaching and learning process of Physics is considered as a situated act, which occurs when students interact with each other using language they understand clearly, communication takes on a central role for both the communicator and the recipient of the information (Charamba, 2019).

Based on research conducted by Rais et al. (2020) it can be concluded that the development of video-based learning contents and activities by adopting the Absorb-Do-Connect (ADC) model can be implemented in blended learning-based classes. According to Kelly et al. (2009) students prefer video-based learning methods because it can help minimize procedural and methodological inconsistencies in teaching skills. However, it is best used to complement rather than replace the teacher/ lecturer function. According to Purwanti (2015) the use of video based for learning mathematics with the ASSURE model can increase the effectiveness of learning and can motivate students to learn mathematics. Referring to the results of the pretest and posttest analysis as well as the paired sample t-test analysis, it is proven that the educational product based on the research in the form of instructional videos is very effective in increasing student understanding to the Principles of 3D Computer Animation (Pambudi et al., 2021).

Furthermore, from the results of the research regarding the development of ecosystem succession learning videos to increase student learning motivation and mastery of biological concepts, it is concluded that the use of instructional videos is very good and instructional video can increase student learning motivation (Handziko \& Suyanto, 2015). Based on the results of descriptive statistics in the study by Istiqomah et al. (2017), it was seen that the conceptual understanding of students who used video was superior to those of the control class who used conventional learning models. Subsequent research conducted by Mutia et al. (2018) shows that the use of video as a learning medium is very feasible as teaching content for students in teaching and learning activities.

The results of the research Putri et al. (2017) obtained a very good predicate and suitable for use in learning. Rusli et al. (2020) stated that the use of Physics learning videos on static fluid content with the STAD type cooperative model was validated very good model and was worthy of being used as a learning medium. According to Agustini and Ngarti (2020) in their research, the results of learning videos really help students in facilitating the learning process and making it easier for teachers to deliver the content. Despite the positives outcomes, in some of the aforementioned studies, there are drawbacks. One of which is in the application of learning videos that require more real examples than the lecture method already used in the learning videos, since these learning videos should provide illustrative examples for students to increase their understanding. Based on the results of previous research, the author is interested in participating in conducting research on the use of instructional videos in the teaching and learning process. The purpose of this study is to identify the results of the development of instructional videos on the atomic theory content in the Tialo language and investigate the students' understanding by using the particular learning media.

\section{Method}

This research draws on the Research and Development (R\&D), which is a research model used to develop educational products and test the effectiveness of these products. The research conducted is the development of teaching contents for modern physics courses using the ADDIE model. The ADDIE model consists of five stages, namely analysis, planning, development, implementation, and evaluation (Widyastuti \& Susiana, 2019), as shown Figure 1. 


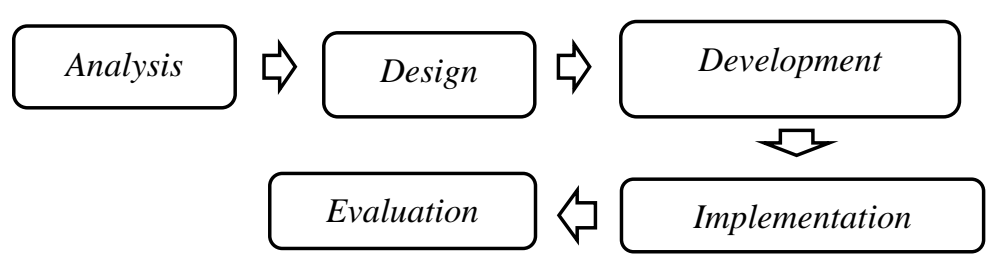

Figure 1. The ADDIE model

The subjects of this study were students of class XI MA AL-KHAIRAAT TOMINI. Since this learning video media uses the mother tongue (Tialo language), the researchers conducted trials on students who were the native people of the Tialo area. Only 10 students became the subjects in this limited research to assess the feasibility of the physics learning video.

The research instrument used in this research is a questionnaire which aims to examine the feasibility of the media in learning. This components of the questionnaire are questions or responses submitted to respondents and validators and based on a Likert scale four. Fourteen respondents consisting of one linguist, one media expert, one subject teacher and 10 grade XI students of MA ALKHAIRAAT TOMINI, responded to the questionnaire.

The analysis technique used to analyze the validation data is based on the calculation of the average value. The determination of this data analysis technique is based on the opinion of Arikunto (2010); Izzah and Saehana (2021) which states that in order to determine the final score ranking on each questionnaire item, the number of values obtained is divided by the number of respondents who answered the questionnaire. The average scores are displayed in Tables 1 and 2.

Table 1. Product Assessment Criteria

\begin{tabular}{cc}
\hline Average Score & Criteria \\
\hline $3.25<\bar{X} \leqslant 4.00$ & Very Good (VG) \\
$2.50<\bar{X} \leqslant 3.25$ & Good (G) \\
$1.75<\bar{X} \leqslant 2.50$ & Less Good (L) \\
$1.00 \leqslant \bar{X} \leqslant 1.75$ & Very Less (VL) \\
\hline
\end{tabular}

Table 2. Student Response Category Criteria

\begin{tabular}{cc}
\hline Average Score & Criteria \\
\hline $3.25<\bar{X} \leqslant 4.00$ & Strongly Agree (SA) \\
$2.50<\bar{X} \leqslant 3.25$ & Agree (A) \\
$1.75<\bar{X} \leqslant 2.50$ & Disagree (D) \\
$1.00 \leqslant \bar{X} \leqslant 1.75$ & Strongly Disagree (SD) \\
\hline
\end{tabular}

(Mardapi, 2008, p. 84)

The assessment score or the level of feasibility of each aspect or the entire Tialo language physics learning video is made in the form of a table as a reference for assessing the data generated from the validity of the media expert to make it easier to provide values according to the expected criteria. Based on this score, the specifications of this product are in accordance with the students' ability to understand the content being taught, although there are limitations in conducting this research, namely conditions and circumstances that do not allow it to be conducted directly at school.

\section{Results and Discussion}

The content expert is the validator chosen to assess the suitability of aspects of the curriculum, content presentation and language. Validation was carried out by physics education lecturers. In general, content expert validation is carried out by content experts. The results obtained from the content expert's assessment on the feasibility aspect of the content can be seen in Table 3 . 
Table 3. Validation Results of Content Feasibility Aspects

\begin{tabular}{clcc}
\hline No. & \multicolumn{1}{c}{ Indicator } & $\begin{array}{c}\text { Score } \\
\text { Indicator }\end{array}$ & Classification \\
\hline 1. & $\begin{array}{l}\text { Suitability of learning media content with basic competencies and learning } \\
\text { objectives. }\end{array}$ & 4 & Very Good \\
2. & The truth of the concept of the content is viewed from a scientific aspect. & 3 & Good \\
3. & Clarity of learning topics. & 3 & Good \\
4. & Content wrinkling. & 4 & Very Good \\
5. & Content coverage. & 3 & Good \\
6. & Clarity of examples given. & 3 & Good \\
7. & The accuracy of the dialogue/story text with the content. & 3 & Good \\
\hline & Average & 3.28 & Very good \\
\hline
\end{tabular}

Furthermore, an assessment of the aspect of linguistic feasibility can be seen in Table 4 .

Table 4. Validation Results of Linguistic Feasibility Aspects

\begin{tabular}{clcc}
\hline No. & \multicolumn{1}{c}{ Indicator } & Score Indicator & Classification \\
\hline 1. & Ease of understanding the flow of content through the use of language. & 3 & Good \\
2. & Politeness in using language & 4 & Very Good \\
3. & Text accuracy with content & 3 & Good \\
\hline \multicolumn{2}{c}{ Average } & 3.33 & Very Good \\
\hline
\end{tabular}

The results obtained from the assessment on the aspect of linguistic feasibility can be classified as very good. Furthermore, there is an assessment of the feasibility aspect of the presentation, which can be seen in Table 5.

Table 5. Results of Validation of Presentation

\begin{tabular}{llcc}
\hline No. & \multicolumn{1}{c}{ Indicator } & $\begin{array}{c}\text { Score } \\
\text { Indicator }\end{array}$ & Classification \\
\hline 1. & Learning video media support for student involvement in the learning process. & 4 & Very Good \\
2. & Display image presentation & 3 & Good \\
3. & Video clarity that supports understanding of the content. & 2 & Less Good \\
\hline & Average & 3.00 & Good \\
\hline
\end{tabular}

From the results of this assessment, the presentation feasibility aspect can be classified as good. Then there is an assessment of the feasibility aspect of the effect of instructional video media on learning strategies which can be seen in Table 6.

Table 6. Results of Validation of Video Media Effects on Learning Strategies

\begin{tabular}{|c|c|c|c|}
\hline No. & Indicator & $\begin{array}{c}\text { Score } \\
\text { Indicator }\end{array}$ & Classification \\
\hline 1. & Ease of use & 3 & Good \\
\hline 2. & $\begin{array}{l}\text { The ability of learning video media to increase student motivation in studying } \\
\text { physics. }\end{array}$ & 4 & Very Good \\
\hline 3. & The ability of Learning video media increases knowledge. & 3 & Good \\
\hline 4. & The ability of learning video media broadens students' horizons. & 3 & Good \\
\hline & Average & 3.25 & Good \\
\hline
\end{tabular}

In general, the results obtained from the content expert's assessment can be seen in Table 7.

Table 7. Results of Feasibility Validation By Content Expert

\begin{tabular}{clcc}
\hline No. & Assessment Aspects (contain more than one indicator) & Average of score indicator & Category \\
\hline 1. & Content feasibility aspects & 3.28 & Very Good \\
2. & Language feasibility & 3.33 & Very Good \\
3. & Serving feasibility & 3.00 & Good \\
4. & Feasible effect video media learning against strategies learning & 3.25 & Good \\
\hline \multicolumn{1}{r}{ Average } & 3.25 & Good \\
\hline
\end{tabular}


Based on these data, the assessment given by content experts on the Tialo language video can be interpreted overall as good. Thid shows that the instructional video media is feasible to be tested. From the results, there are several shortcomings which lead to a number of suggestions for improvement include: adjusting the text/font to the screen, exposing image or video with a text translation if necessary, balancing the intermediate volume between the explanation from the source to the video sound, and fixing the content delivery in terms of audio and visual explanations to make it easy to understand.

To determine the feasibility of the use of the application by the teachers, they were given sheets ratings which are associated with the application. The results of the assessment by the teachers can be seen in Table 8.

Table 8. Results of Feasibility Test by Student Teachers

\begin{tabular}{clcc}
\hline No. & \multicolumn{1}{c}{ Indicator } & Average Score Indicator & Classification \\
\hline 1. & Curriculum & 4 & Very Good \\
2. & Presentation of content & 3 & VeryGood \\
3. & Language & 4 & Very Good \\
\hline \multicolumn{2}{c}{ Average } & 3.87 & Very Good \\
\hline
\end{tabular}

Based on these data, the assessment given by the physics teacher to the Tialo physics learning video can be interpreted very good, which shows that the Tialo language learning video is suitable for use as a learning medium. It is in line with the teachers' comments about the content provided which is well organized according to the picture so that it is very clear and easy to understand. Also, the use of communicative language is very suitable for the level of development of students.

On the other hand, there are also the results of the student responses. At this stage, the researchers conducted initial product tests and limited trials which intended to determine student product assessments so that later they could be widely used. The trial was limited to 10 students of MA AL-KHAIRAAT Tomini. The results of the limited trial can be seen in Table 9.

Table 9. Analysis Results Average Assessment of Student Response $(n=10)$

\begin{tabular}{|c|c|c|}
\hline No. & Statement & $\begin{array}{l}\text { Average } \\
\text { score }\end{array}$ \\
\hline 1. & $\begin{array}{l}\text { Illustrations which are given in the video medium of learning is very clear and related to } \\
\text { the life everyday }\end{array}$ & 3.2 \\
\hline 2. & $\begin{array}{l}\text { Image and animation are presented in the video medium of learning in accordance with } \\
\text { the content }\end{array}$ & 3.6 \\
\hline 3. & The video that is presented can increase enthusiasm for learning & 3.6 \\
\hline 4. & $\begin{array}{l}\text { This instructional video media makes it easier to understand content through videos } \\
\text { and local languages }\end{array}$ & 3.6 \\
\hline 5. & The local language used is easy to understand & 3.5 \\
\hline 6. & Can be an alternative source of learning & 3.5 \\
\hline 7. & Using this instructional video media can make learning Physics not boring & 3.7 \\
\hline 8. & The image presented is attractive & 3.1 \\
\hline 9. & This instructional video media is easy to use & 3.7 \\
\hline 10. & This instructional video media allows me to learn physics independently & 3.7 \\
\hline 11. & $\begin{array}{l}\text { The instructional video media motivated me to study physics, especially the subject of } \\
\text { atomic theory }\end{array}$ & 3.4 \\
\hline 12. & This instructional video media broadened my horizons. & 3.6 \\
\hline 13. & The writing is easy to read & 3.5 \\
\hline 14. & The suitability of images and contents made me more excited to study physics & 3.5 \\
\hline \multirow[t]{2}{*}{15.} & Appealing media appearance/design & 3.5 \\
\hline & Average & 3.51 \\
\hline
\end{tabular}

Based on these data, an average score of 3.51 was obtained. This assessment means that students strongly agree if video is used in the learning process. The purpose of this research is that the writer wants to know the results of the development of the earning video on atomic theory in 
the Tialo language and to see the level of understanding of the students in learning using the Tialo language video.

Furthermore, the results of the linguist's assessment carried out by one of the native speakers of the Tialo language, the aspects assessed from the Tialo language physics learning video include language eligibility. So that if analyzed as a whole, an average value of 3.33 will be obtained. Based on these data, the assessment given by the linguist on the physics learning video in this language can be interpreted properly so that it is feasible to be tested. Furthermore, the results of the media expert's assessment conducted by physics education lecturers, the aspects assessed from the Tialo language physics learning video include linguistic feasibility, visual appearance, media effects about learning strategies and display software. So that if analyzed as a whole, an average value of 3.28 will be obtained. Based on these data, the assessment given by media experts on the Tialo physics learning video can be interpreted properly so that it is feasible to be tested.

The initial appearance of this instructional video still has several shortcomings, especially in the part of the image that has a lace resolution, which can be seen in Figure 2.

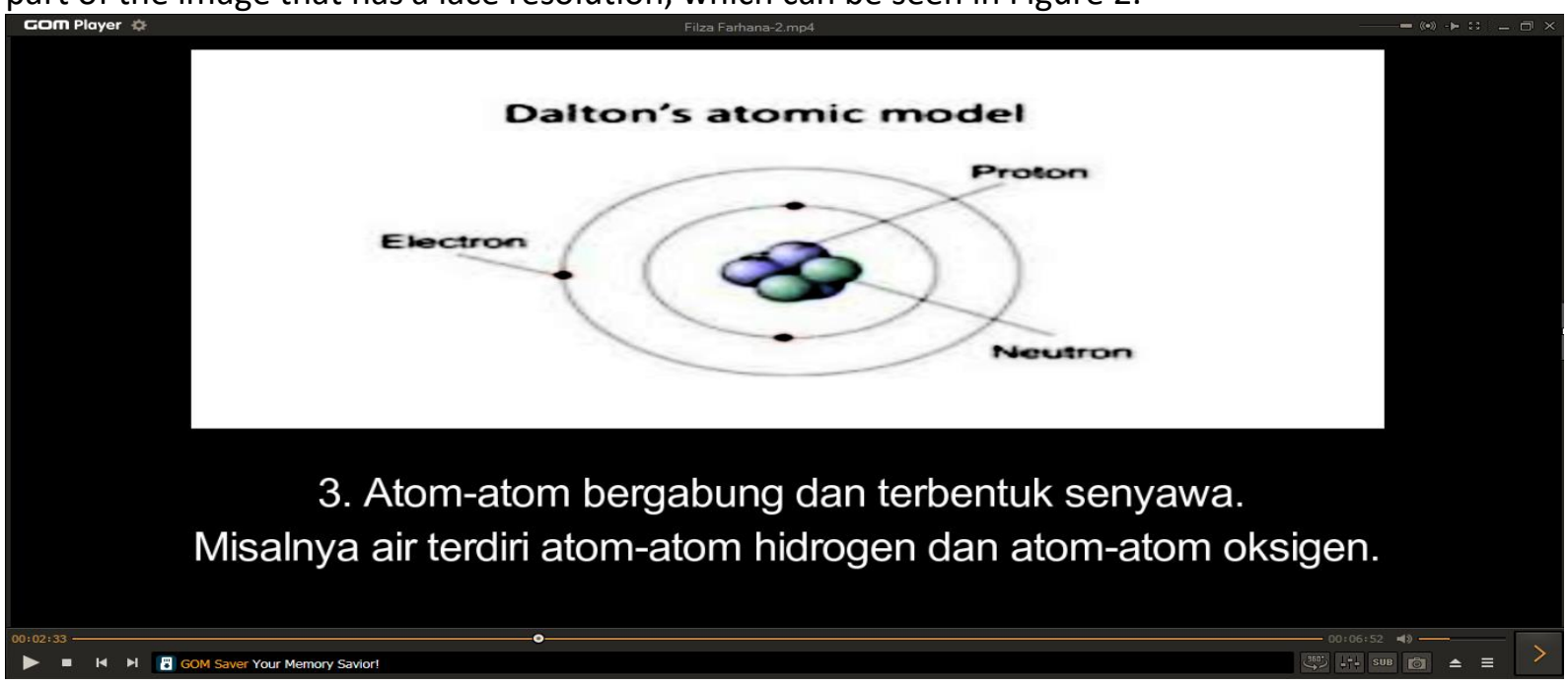

Figure 2. Display of video media before upgrade

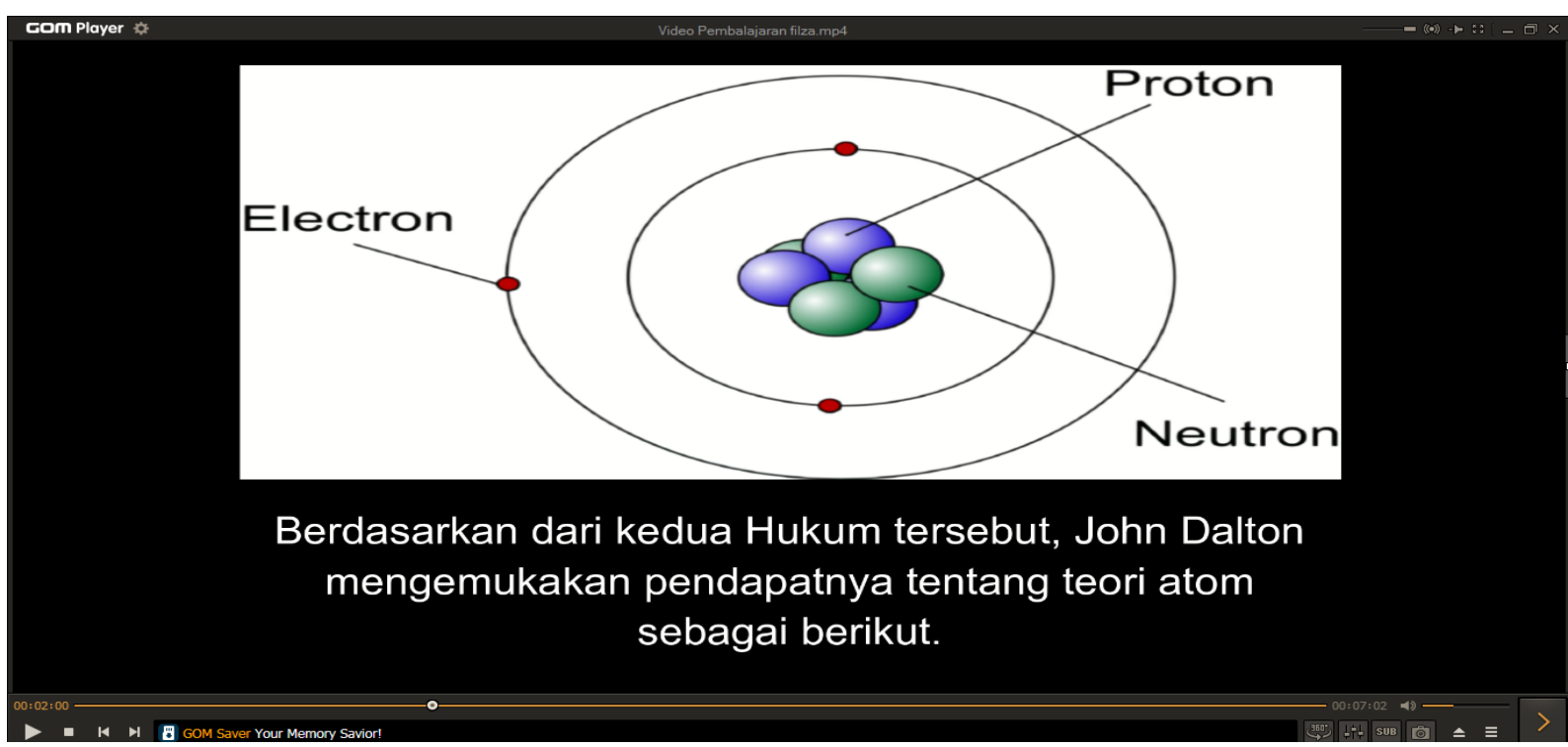

Figure 3. Display of instructional video media after repair

(https://drive.google.com/file/d/11kOJ96UFLeedw6sWTUTO60QV-FhH43J-/view?usp=sharing)

After being declared feasible by content experts, linguists and media experts, the Tialo language physics learning video media was tried out in the feasibility test of learning practitioners (teachers). The feasibility test was carried out by the MA AL-KHAIRAAT Tomini teacher. The aspects 
that were assessed from the Tialo language physics learning video included the curriculum, content presentation, and language. The average overall assessment of learning practitioners (teachers) was 3.87.

The improvements made by researchers were adding image resolution to the video display, fixing the text and improving the audio narrative voice of the video. This can be seen in Figure 3 . The development of the Tialo-language physics instructional video media undergone through 4 stages, namely Analysis, Design, Development, and Implementation. The manufacturing process is carried out in stages starting with finding information and references from several books, archives and articles, then the learning video product design stage is looking for references in the form of pictures related to atomic theory content, compiling a summary of the content then translated into Tialo language with the help of the native speakers of Tialo language, then video shooting and the voice recording of the narrator. After that, the editing and mixing process is carried out and finally compiling the instruments that will be used in the research. The next stage is validation or a video feasibility test, which is done by three validators and one physics teacher. At this stage, there are several shortcomings of the learning media and improvements are made for better results. After the instructional video media was good enough, trials were carried out on several students, this was done during the implementation stage. In this study, the evaluation stage has not been carried out because this study was still a small-scale study while the evaluation stage was usually carried out on a large-scale.

Furthermore, the initial product test was carried out in order to determine the student's assessment of the development product that had been produced, in the form of a physics learning video in Tialo. Learning media development results were tested on 10 students. The purpose of implementing product trials is to get an overview of student responses to the product being developed. In this study, students assessed the content, language, and their interests in using these learning media. The results of the analysis of the students' assessment of the physics learning video media for the atomic theory content developed are presented as follows: because the type of statement is positive, the score for each answer option is as follows: 4; Strongly agree, 3; Agree, 2; Disagree, 1 ; Strongly disagree.

Product trials were carried out on class XI IPA MA AL-KHAIRAAT Tomini, where students were given a questionnaire containing 15 question items. After analyzing the questionnaire given to 10 students, the average score was 3.51. This assessment can be interpreted that students strongly agree if the physics learning video in Kaili is used in the learning process in the classroom both guided and independently.

After the revision stage of the selection is carried out, then it is followed by a limited trial. This limited trial was conducted on a small scale to 10 students of MA-ALKHAIRAAT TOMINI. This limited trial assessment was carried out by giving 5 questions in the form of description questions to students regarding the content presented in the instructional video media. This was done in order to find out whether the student was able to understand the explanation of the atomic theory content in the Tialo language described in the learning video. Of the 10 students who were given questions in the limited test, there were 8 of them who had very high abilities in understanding the explanation of the atomic theory in the Tialo language, 1 of them had moderate abilities and 1 student had low abilities. Based on the results of this limited trial, an average value of 85.5 was obtained as shown in Table 10, which means that $80 \%$ of students understood the content described and were able to answer the description questions well. The advantages of physics learning videos on atomic theory content students can see the content exposure repeatedly and can increase students' understanding of the content of atomic theory.

After conducting a limited trial of 10 students, it can be concluded that the use of video media in learning makes students more enthusiastic in the learning process because the delivery of content is not monotonous, so that students are more motivated. In addition, students can use video media repeatedly in independent learning.

This study emphasizes the aspects of student understanding of the Tialo language learning video media. From the results, it was found that instructional videos were very suitable for use in the 
teaching and learning process, as well as research conducted by Kristanto et al. (2017) who stated that the development of instructional media products in a course learning activity in the form of audio/video development is very feasible to use in the learning process. Likewise, (Sumbawat \& Munoto, 2016) stated that all learning videos are suitable for use in learning, since the development of videos is time consuming and tiring. Therefore, experts are needed to shoot and edit the video to fit the synopsis and treatment that has been prepared.

Table 10. Average Results of Limited Trial Assessment $(n=10)$

\begin{tabular}{|c|c|c|c|c|c|c|c|c|}
\hline \multirow{2}{*}{ No. } & \multirow{2}{*}{ Respondents } & \multicolumn{5}{|c|}{ Problem Number } & \multirow{2}{*}{ Total Score } & \multirow{2}{*}{ Score } \\
\hline & & 1 & 2 & 3 & 4 & 5 & & \\
\hline 1. & $\mathrm{R} 1$ & 3 & 4 & 4 & 4 & 4 & 19 & 95.0 \\
\hline 2. & $\mathrm{R} 2$ & 3 & 4 & 4 & 4 & 1 & 16 & 80.0 \\
\hline 3. & R3 & 4 & 4 & 4 & 4 & 4 & 20 & 100.0 \\
\hline 4. & $\mathrm{R} 4$ & 3 & 3 & 4 & 3 & 2 & 15 & 75.0 \\
\hline 5. & R5 & 3 & 3 & 1 & 2 & 3 & 12 & 60.0 \\
\hline 6. & $\mathrm{R} 6$ & 4 & 3 & 4 & 4 & 3 & 18 & 90.0 \\
\hline 7. & R7 & 3 & 3 & 4 & 3 & 4 & 17 & 85.0 \\
\hline 8. & $\mathrm{R} 8$ & 4 & 4 & 3 & 4 & 4 & 19 & 95.0 \\
\hline 9. & R9 & 3 & 3 & 4 & 4 & 3 & 17 & 85.0 \\
\hline 10. & R10 & 3 & 4 & 4 & 4 & 3 & 18 & 90.0 \\
\hline \multicolumn{8}{|c|}{ Average } & 85.5 \\
\hline
\end{tabular}

The positive assessment of this student is most likely because previously the school had not used the instructional video media, let alone explained in the local language, so that it made them feel bored and did not understand the physics learning video. In this learning video, there are explanations made in sentences that are easy for students to understand, so that participants can study the content even without a teacher. Meanwhile, the students' assessment is not good, namely because the display of instructional video media has a display in the form of images and colors that are less attractive.

This research is in line with the research conducted by Ardini et al. (2019) but what distinguishes this research from previous research is in terms of language, where the language used in the current research is Tialo language, both from the researcher's own area and within data collection which is only done online. The development of instructional video media has not yet been fully implemented. There are limitations in this study on the development of instructional video media, namely the use of Filmora 7.8.9 software which experienced problems during the editing process so that researchers had to reinstall the Filmora 9.5.0.20 software. In addition, it is not possible to carry out direct research in schools because the Covid-19 pandemic has not ended so data collection is only done online. Researchers also experienced difficulties in finding respondents because students in the Tomini Village Area, Tomini District, Parigi Moutong Regency rarely used smartphones. In addition, this video media contains several concepts of immovable content such as animation, where the concept of content like this is difficult to explain in learning media such as video, but must be explained directly to make it easier to understand.

\section{Conclusion}

Based on the results of the research and discussion, it can be concluded that the software in the form of the Tialo language physics learning video produced can be used to help learning physics subjects on atomic theory. The results of product quality validation based on the expert, media, and content assessments are in the good category. Meanwhile, the scores obtained from the teachers and students of class XI IPA were in the "Strongly Agree" category. The results showed that the learning video on atomic theory in the Tialo language was suitable for use in learning activities and could increase the concentration level of students. Based on the results of research and development, further research would be to develop this product on other contents and topics. In addition, further 
research is needed with broader trials in accordance with the ADDIE steps in using instructional video, as well as developing this product by making a more attractive design and clearer sound.

\section{References}

Agustini, K., \& Ngarti, J. G. (2020). Pengembangan video pembelajaran untuk meningkatkan motivasi belajar siswa menggunakan model R\&D. Jurnal Imiah Pendidikan Dan Pembelajaran, 4(1), 6278. https://doi.org/10.23887/jipp.v4i1.18403

Ardini, Y. D., Ismail, N. N., Azni, N. D. M., \& Harun, N. A. (2019). Molar incisor hypomineralisation: Prevalence and associated risk factors among children at the Polyclinic, Kulliyyah of Dentistry, IIUM. Materials Today: Proceedings, 16, 2351-2356. https://doi.org/10.1016/j.matpr.2019.06.138

Arikunto, S. (2010). Prosedur penelitian: Suatu pendekatan praktik. Rineka Cipta.

Charamba, E. (2019). Learning and language: towards a reconceptualization of their mutual interdependences in a multilingual science class. Journal of Multilingual and Multicultural Development, O(0), 1-19. https://doi.org/10.1080/01434632.2019.1707837

Correia, A. P., Koehler, N., Thompson, A., \& Phye, G. (2019). The application of PhET simulation to teach gas behavior on the submicroscopic level: secondary school students' perceptions. Research in Science and Technological Education, 37(2), 193-217. https://doi.org/10.1080/02635143.2018.1487834

Crouch, C. H., Wisittanawat, P., Cai, M., \& Renninger, K. A. (2018). Life science students' attitudes, interest, and performance in introductory physics for life sciences: An exploratory study. Physical Review Physics Education Research, 14(1), 10111. https://doi.org/10.1103/PhysRevPhysEducRes.14.010111

Handziko, R. C., \& Suyanto, S. (2015). Pengembangan video pembelajaran suksesi ekosistem untuk meningkatkan motivasi belajar dan penguasaan konsep mahasiswa biologi. Jurnal Inovasi Pendidikan IPA, 1(2), 212. https://doi.org/10.21831/jipi.v1i2.7508

Istiqomah, P., Werdhiana, I. K., \& Wahyono, U. (2017). Pengaruh penggunaan media video terhadap peningkatan pemahaman konsep suhu dan kalor pada siswa kelas X MAN 1 Palu. JPFT (Jurnal Pendidikan Fisika Tadulako Online), 5(3), 28. https://doi.org/10.22487/j25805924.2017.v5.i3.8868

Izzah, A., \& Saehana, S. (2021). Developing video-based learning for the application of ohm's law towards conductive transparent layer. Journal of Physics: Conference Series, 1760(1). https://doi.org/10.1088/1742-6596/1760/1/012043

Kelly, M., Lyng, C., McGrath, M., \& Cannon, G. (2009). A multi-method study to determine the effectiveness of, and student attitudes to, online instructional videos for teaching clinical nursing skills. Nurse Education Today, 29(3), 292-300. https://doi.org/10.1016/j.nedt.2008.09.004

Lee, S., \& Lee, B. (2018). Analysis of middle school science teachers' difficulties in teaching physics inquiry in textbooks. New Physics: Sae Mulli, 68(4), 411-421. https://doi.org/10.3938/NPSM.68.411

Mardapi, D. (2008). Teknik penyusunan instrumen tes dan nontes. Mitrs Cendikia Offset.

Mutia, R., Adlim, A., \& Halim, A. (2018). Pengembangan video pembelajaran IPA pada materi pencemaran dan kerusakan lingkungan. Jurnal Pendidikan Sains Indonesia, 5(2), 110-116. https://doi.org/10.24815/jpsi.v5i2.9825

Nurrita, T. (2018). Pengembangan media pembelajaran untuk meningkatkan hasil belajar siswa. MISYKAT: Jurnal IImu-IImu Al-Quran, Hadist, Syari'ah Dan Tarbiyah, 3(1), 171. https://doi.org/10.33511/misykat.v3n1.171

Pambudi, S., Hidayatulloh, I., Surjono, H. D., \& Sukardiyono, T. (2021). Development of instructional 
videos for the principles of 3D computer animation. Journal of Physics: Conference Series, 1737(1), 012022. https://doi.org/10.1088/1742-6596/1737/1/012022

Price, E., Lau, A. C., Goldberg, F., Turpen, C., Smith, P. S., Dancy, M., \& Robinson, S. (2021). Analyzing a faculty online learning community as a mechanism for supporting faculty implementation of a guided-inquiry curriculum. International Journal of STEM Education, 8(1). https://doi.org/10.1186/s40594-020-00268-7

Purwanti, B. (2015). Pengembangan media video pembelajaran matematika dengan model assure. Jurnal Kebijakan Dan Pengembangan Pendidikan, 3(1). https://doi.org/10.22219/jkpp.v3i1.2194

Putri, N. M. L. K., Parmiti, D. P., \& Sudarma, I. K. (2017). Pengembangan video pembelajaran dengan bahasa isyarat berbasis pendidikan karakter pada siswa kelas $V$ di SDLB-B Negeri I Buleleng tahun pelajaran 2017/2018. Jurnal Edutech Undiksha, 7(2), 81-91. https://doi.org/10.23887/jeu.v7i2.23162

Rais, M., Rifai, A. A., Hartoto, Yusri, \& Fadillah, R. (2020). Blended learning on the development of instructional videos to improve abilities in learning about concepts and procedures. Proceedings of the International Conference on Online and Blended Learning 2019 (ICOBL 2019). https://doi.org/10.2991/assehr.k.200521.024

Rusli, R., Kendek, Y., \& Saehana, S. (2020). Development of physics learning videos on static fluid contents with the stad type cooperative model. Online Creative Journal, 8(2), 112-120.

Sumbawat, M. S., \& Munoto, M. (2016). The development of instructional video to illustrate how teaching in a real learning environment. Proceedings of the 2015 International Conference on Innovation in Engineering and Vocational Education. https://doi.org/10.2991/icieve15.2016.37

Widyastuti, E., \& Susiana. (2019). Using the ADDIE model to develop learning material for actuarial mathematics. Journal of Physics: Conference Series, 1188, 012052.

https://doi.org/10.1088/1742-6596/1188/1/012052 